\title{
SINTESIS DAN KARAKTERISASI SENYAWA KOMPLEKS Zn(II)-EDTA SEBAGAI SENYAWA ANTIALGA PADA COOLING WATER INDUSTRI
}

\author{
Harsasi Setyawati*, Sri Sumarsih, Sevia Ayuningtyas \\ Department of Chemistry, Faculty of Science and Technology, \\ Airlangga University \\ *email: harsasi85@gmail.com
}

Received 20 Februari 2017 Accepted 20 April 2017

\begin{abstract}
Abstrak
Telah berhasil dilakukan penelitian tentang sintesis, karakterisasi serta uji aktivitas penghambatan alga menggunakan senyawa kompleks Zn(II)-EDTA pada sampel cooling water industri. Penelitian ini bertujuan untuk mengetahui potensi senyawa kompleks $\mathrm{Zn}(\mathrm{II})-\mathrm{EDTA}$ sebagai material penghambat pertumbuhan alga yang hidup pada cooling water pond di industri. Senyawa kompleks $\mathrm{Zn}(\mathrm{II})$-EDTA berhasil disintesis dengan perbandingan mol Zn: EDTA adalah 1:1. Senyawa kompleks Zn(II)-EDTA memiliki panjang gelombang maksimal pada $752 \mathrm{~nm}$. Ikatan Zn-O pada EDTA muncul pada bilangan gelombang $478,35 \mathrm{~cm}^{-1}$ dan Zn-N pada EDTA muncul pada bilangan gelombang $516,92 \mathrm{~cm}^{-1}$. Senyawa kompleks Zn(II)-EDTA mampu menghambat pertumbuhan alga sebesar $98 \%$ untuk alga hijau dan $87 \%$ untuk alga coklat jika dibandingkan dengan sampel dengan perlakuan kontrol positif Seyton.
\end{abstract}

Kata kunci: Kompleks Zn(II)-EDTA, cooling water, antialga, alga hijau, alga coklat

\begin{abstract}
Have been successfully done a research about synthesis, characterization and algae inhibition assay of Zn(II)-EDTA complexes in sample cooling water on industry. The purpose of the research is to observe the potential of $\mathrm{Zn}(\mathrm{II})$-EDTA complexes as algae inhibitor material in cooling water pond of industry. This complexes have been synthesized with mole ratio of $\mathrm{Zn}$ :EDTA $=1: 1$. The maximum wavelength of the complexes is $752 \mathrm{~nm}$. The bonding of $\mathrm{Zn}-\mathrm{O}$ from EDTA and $\mathrm{Zn}-\mathrm{N}$ from EDTA in sequence is $478.83 \mathrm{~cm}^{-1}$ and $516.92 \mathrm{~cm}^{-1}$. Complexes of $\mathrm{Zn}$ (II)-EDTA potentially inhibit algae growth $98 \%$ for green algae and $87 \%$ for brown algae if compared with positive control Seyton.
\end{abstract}

Keywords: Zn(II)-EDTA complexes, cooling water, antialgae, green algae, brown Algae

\section{Pendahuluan}

Salah satu kebutuhan utama pada proses industri adalah air pendingin (cooling water). Air yang digunakan sebagai pendingin tersebut harus memiliki kandungan padatan terlarut rendah, bebas mikroorganisme terutama jamur dan lumut, dan tidak korosif (Widiasa dkk, 2005). Sistem pendinginan air yang biasa digunakan pada industri biasanya 
menggunakan sistem sirkulasi terbuka. Panas yang terkandung dalam cooling water dilepaskan keudara melalui kontak langsung. Proses pendinginan sistem terbuka ini mengakibatkan cooling water terkontaminasi oleh mikroorganisme dari udara, seperti alga. Jika air pendingin yang mengandung alga tersebut digunakan pada proses produksi, maka mesin pendingin akan mengalami korosif dan lumutan sehingga proses pendinginan menjadi kurang maksimal dan proses produksi akan terganggu. Adanya mikroorganisme pada cooling water harus segera diatasi sehingga tidak menimbulkan permasalahan lebih lanjut.

Pada penelitian ini telah berhasil diteliti material penghambat pertumbuhan mikroorganisme/alga pada cooling water menggunakan senyawa kompleks Zn(II)EDTA. Berdasarkan Paten No. 2002098231 AI, senyawa $\mathrm{Na}_{2}$ EDTA memiliki kemampuan menghambat dan mencegah pertumbuhan alga dan bakteri dalam air. Pada penelitian ini, kemampuan penghambatan EDTA ditingkatkan dengan menambahkan ion logam pada senyawa EDTA. Senyawa EDTA memiliki kemampuan agen pengkhelat yang baik dan membentuk senyawa kompleks yang sangat stabil dengan ion logam divalen (Satroutdinov $\mathrm{dkk}, 2000)$ serta larut dalam air (Tarasov, 2011). Logam Zn dipilih karena memiliki sifat oligodinamik yaitu daya pada logam dimana pada konsentrasi yang kecil saja dapat membunuh mikroba seperti bakteri dan alga.

Senyawa kompleks Zn(II)-EDTA disintesis dengan perbandingan mol logam dan ligan $=1: 1$ dan dikarakterisasi dengan instrumen spektrofotometer UVVis dan spektrofotometer Fourier Transform Infrared (FTIR). Aktivitas penghambatan senyawa kompleks $\mathrm{Zn}$ (II)EDTA diuji dengan menganalisis perpendaran alga menggunakan instrument spektrofotometer UV-Vis dan menganalisis berat sel kering alga. Pada penelitian ini, aktivitas penghambatan senyawa kompleks Zn(II)-EDTA dibandingkan dengan kontrol positif senyawa Seyton yang biasa digunakan di dunia industri.

\section{Metode Penelitian}

Alat dan Bahan

Bahan kimia yang digunakan dalam penelitian ini adalah derajat pro analysis. Bahan-bahan yang digunakan untuk sintesis $\mathrm{Zn}(\mathrm{II})$-EDTA antara lain $\mathrm{ZnCl}_{2}$ anhidrat, $\mathrm{Na}_{2}$ EDTA, akuades, dan metanol 98\%. Sedangkan bahan yang digunakan untuk uji antialga adalah sampel air dari cooling water dan senyawa biocide merk Seyton.

Peralatan yang digunakan pada penelitian ini adalah Alat-alat yang digunakan dalam penelitian ini adalah gelas ukur, gelas beaker, botol reagen, hot plate, stirrer, batang pengaduk, botol semprot, kaca arloji, timbangan analitik, oven, kertas saring dan Laminar Air Flow. Instrumen yang digunakan adalah spektrofotometer Shimadzu UV-Vis 1800 dan spektrofotometer Jasco FT-IR 5300.

\section{Prosedur Penelitian}

Penelitian ini diawali dengan mensintesis senyawa kompleks $\mathrm{Zn}$ (II)EDTA dengan perbandingan mol logam : ligan $=1:$. Masing-masing senyawa dilarutkan dalam akuades selanjutnya kedua larutan dicampurkan dan dipanaskan pada suhu rendah selama 1 jam. Proses sintesis dihentikan ketika volume larutan telah mencapai sepertiga volume awal. Selanjutnya larutan didinginkan dan disaring sehingga diperoleh endapan dan filtat. Filtrat yang diperoleh didiamkan selama beberapa hari pada suhu ruang sampai terbentuk kristal. Kristal yang terbentuk direkristalisasi dan dikarakterisasi dengan instrumen spektrofotometer UV-Vis dan spektrofotometer FTIR.

Pada penelitian ini digunakan tiga set sampel cooling water yang berbeda untuk uji penghambatan pertumbuhan alga. Setiap set sampel cooling water pada 
volume yang sama diukur perpendaran alganya sebelum diberi perlakuan menggunakan spktrofotometer UV-VIS pada panjang gelombang $590 \mathrm{~nm}$ dan 550 $\mathrm{nm}$. Set sampel pertama adalah sampel cooling water yang mengandung alga tanpa penambahan senyawa apapun sebagai kontrol negatif. Set sampel kedua adalah sampel cooling water yang mengandung alga yang telah ditambahkan senyawa Seyton 10 ppm sebagai kontrol positif. Set sampel ketiga adalah sampel cooling water yang mengandung alga yang telah ditambahkan senyawa kompleks Zn(II)-EDTA dengan variasi konsentrasi 5 ppm, 10 ppm, 50 ppm, 100 ppm. Selanjutnya semua sampel dishaker selama 24 jam. Setelah 24 jam, semua sampel diukur absorbansinya pada panjang gelombang $590 \mathrm{~nm}$ untuk menganalisis adannya alga hijau dan 550 $\mathrm{nm}$ untuk menganalisis adannya alga coklat. Sebagai pembanding, setiap set sampel dianalisis berat keringnya dengan cara menyaring sampel cooling water yang mengandung alga yang telah didiamkan selama 24 jam dengan menggunakan kertas saring. Kertas saring tersebut kemudian dikeringkan dengan cara dioven pada suhu rendah selama 1 jam. Setelah 1 jam, kertas saring didinginkan dan kemudian ditimbang untuk mengetahui berat sel keringnya. Uji aktivitas penghambatan pertumbuhan alga ini dilakukan selama 14 hari berturut-turut pada kondisi sampel yang sama.

\section{Hasil dan Pembahasan}

Sintesis dan karakterisasi senyawa kompleks Zn-EDTA

Penelitian ini telah berhasil dilakukan sintesis senyawa kompleks $\mathrm{Zn}$ (II)-EDTA dari senyawa $\mathrm{ZnCl}_{2}$ dengan ligan $\mathrm{Na}_{2}$ EDTA. Hasil dari sintesis diperoleh senyawa kompleks Zn(II)-EDTA berbentuk kristal berwarna putih keruh. Senyawa kompleks hasil sintesis dikarakterisasi panjang gelombang maksimalnya menggunakan spektrofotometer UV-Vis dan dikarakterisasi gugus fungsinya menggunakan spektrofotometer FTIR. Adapun hasil karakterisasi senyawa ZnEDTA dengan spektrofotometer UV-VIS disajikan pada Tabel 1 dan hasil karakterisasi senyawa Zn-EDTA dengan spektrofotometer FTIR disajikan pada Gambar 1.

Tabel 1. Panjang gelombang maksimal senyawa $\mathrm{ZnCl}_{2}$, ligan $\mathrm{Na}_{2}$ EDTA dan senyawa kompleks Zn(II)-EDTA

\begin{tabular}{cc}
\hline Senyawa & $\begin{array}{c}\text { Panjang Gelombang } \\
\text { Maksimum (nm) }\end{array}$ \\
\hline $\mathrm{ZnCl}_{2}$ anhidrat & 652,00 \\
$\mathrm{Na}_{2}$ EDTA & 472,50 \\
Senyawa Kompleks Zn(II)-EDTA & 752,00 \\
\hline
\end{tabular}

Tabel 1 menunjukkan bahwa senyawa kompleks Zn(II)-EDTA memiliki panjang gelombang maksimum yang berbeda dari unsur pembentuknya yaitu $\mathrm{ZnCl}_{2}$ dan EDTA. Munculnya panjang gelombang pada $752,00 \mathrm{~nm}$ menunjukkan adanya pergeseran batokromik, yaitu pergeseran puncak absorbsi ke arah panjang gelombang yang lebih besar. Adanya pergeseran batokromik disebabkan karena struktur senyawa kompleks Zn(II)-EDTA memiliki gugus kromofor (ikatan $\mathrm{C}=\mathrm{O}$ ) dan gugus auksokrom (gugus $\mathrm{OH}$ ) yang berasal dari ligan EDTA. Gugus-gugus tersebut yang menyebabkan senyawa kompleks Zn(II)-EDTA dapat menyerap cahaya pada daerah tampak/visibel (Hendayana, 1994).

Berdasarkan hasil spektra pada Gambar 1 dapat dilihat bahwa terbentuknya senyawa kompleks Zn(II)-EDTA diindikasikan dari munculnya vibrasi gugus $\mathrm{Zn}$ dengan gugus $\mathrm{O}$ dan $\mathrm{N}$ dari ligan EDTA. Pada spektra tersebut vibrasi gugus $\mathrm{Zn}-\mathrm{O}$ 
muncul pada bilangam gelombang 478,35 $\mathrm{cm}^{-1}$ dan vibrasi gugus $\mathrm{Zn}-\mathrm{N}$ pada spektra muncul pada bilangan gelombang 516,92 $\mathrm{cm}^{-1}$. Menurut literatur vibrasi gugus $\mathrm{Zn}$ $\mathrm{O}$ akan muncul pada bilangan gelombang
$486 \mathrm{~cm}^{-1}$ (Palomino, 2006) dan vibrasi gugus $\mathrm{Zn}-\mathrm{N}$ akan muncul pada bilangan gelombang $570,93 \mathrm{~cm}^{-1}$ (Setiyani $\mathrm{R}$, dkk, 2015).

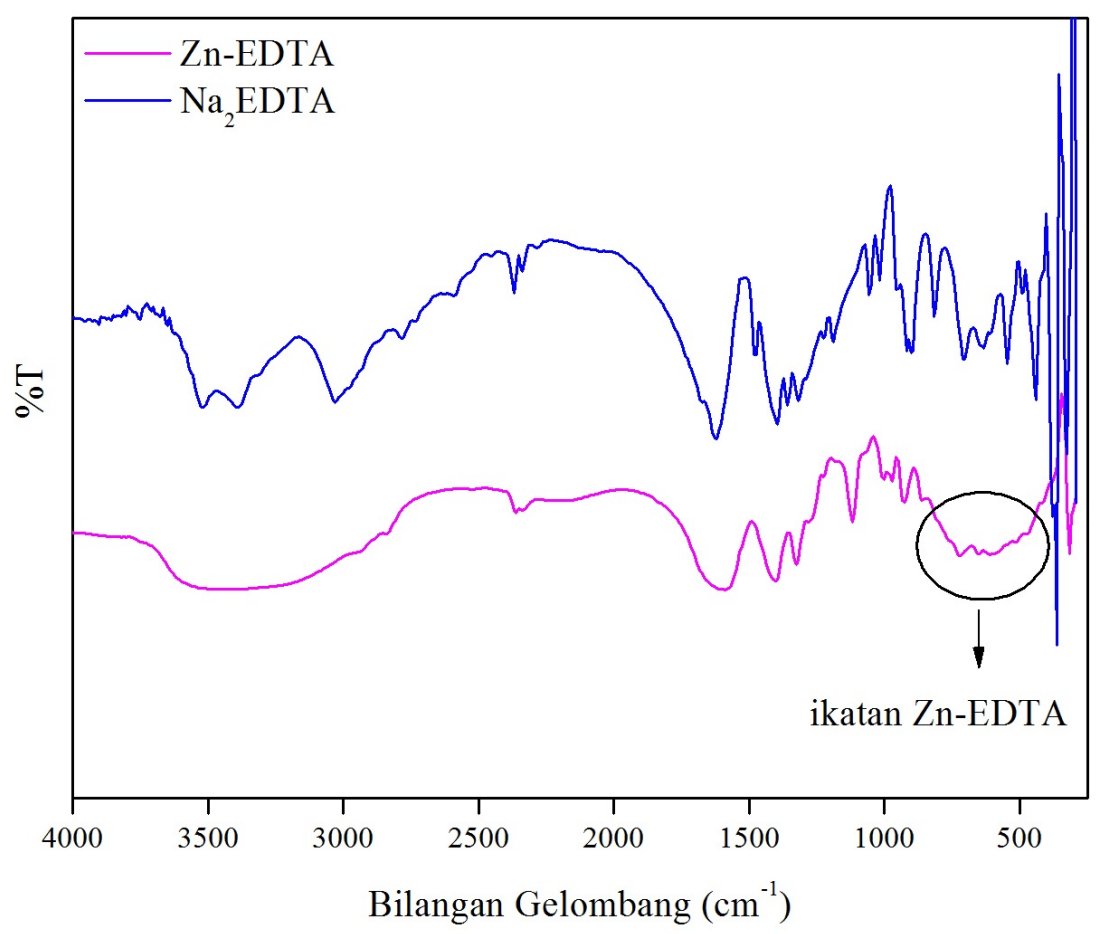

Gambar 1. Hasil FTIR ligan $\mathrm{Na}_{2}$ EDTA dan senyawa kompleks Zn(II)-EDTA

Tabel 2. Tabel Hasil Identifikasi Alga pada Air cooling water

\begin{tabular}{lll}
\hline Jenis & Kelas & Kelompok \\
\hline $\begin{array}{l}\text { Chroococcus } s p . \\
\text { Oscillatoria } s p .\end{array}$ & Cyanophyceae/Cyanobacteria & Alga Hijau \\
Synechococcus $s p$. & Cyanophyceae/Cyanobacteria & Alga Hijau \\
Chlorella $s p$. & Cyanophyceae/Cyanobacteria & Alga Hijau \\
Schizochlamydella $s p$. & Chlorophyceae & Alga Hijau \\
& Chlorophyceae & Alga Hijau \\
Epithemia $s p$. & Diatomeae/Bacillariophyceae & Alga Coklat \\
Stauronets $s p$ & Diatomeae/Bacillariophyceae & Alga Coklat \\
Haematococcus $s p$. & Flagellata/Dinoflagellata & Alga Coklat \\
\hline
\end{tabular}

Uji aktivitas senyawa kompleks Zn(II)EDTA pada penghambatan pertumbuhan alga melalui analisis perpendaran alga

Sebelum proses perlakuan pada sampel cooling water, terlebih dahulu dilakukan identifikasi terhadap sampel cooling water terlebih dahulu. Hal ini untuk membuktikan bahwa pada sampel air pendingin yang akan diteliti mengandung alga. Adapun hasil identifikasi sampel cooling water disajikan pada Tabel 2.

Tabel 2 menunjukkan bahwa kandungan alga yang terdapat pada sampel cooling water adalah alga hijau dan alga coklat. Oleh karena itu pada penelitian ini uji aktivitas penghambatan 

senyawa kompleks $\mathrm{Zn}(\mathrm{II})$-EDTA pada
pertumbuhan alga dilakukan dengan menganalisis perpendaran alga menggunakan spektrofotometer

\section{instrument}

menganalisis berat sel kering alga sebagai pembandingnya. Hasil uji aktivitas penghambatan senyawa kompleks Zn(II)EDTA terhadap alga hijau dan alga coklat disajikan pada Gambar 2, 3 dan 4

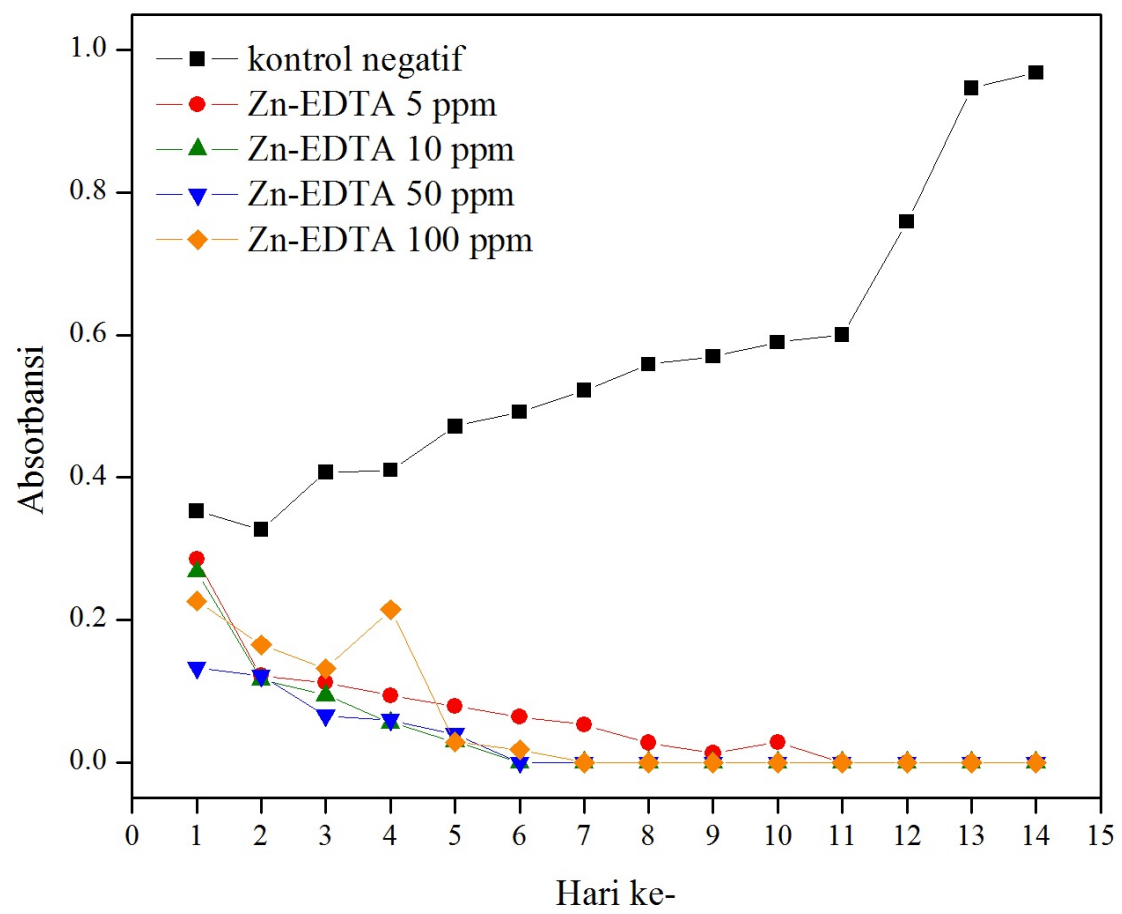

Gambar 2. Aktivitas penghambatan senyawa kompleks Zn(II)-EDTA pada pertumbuhan alga hijau

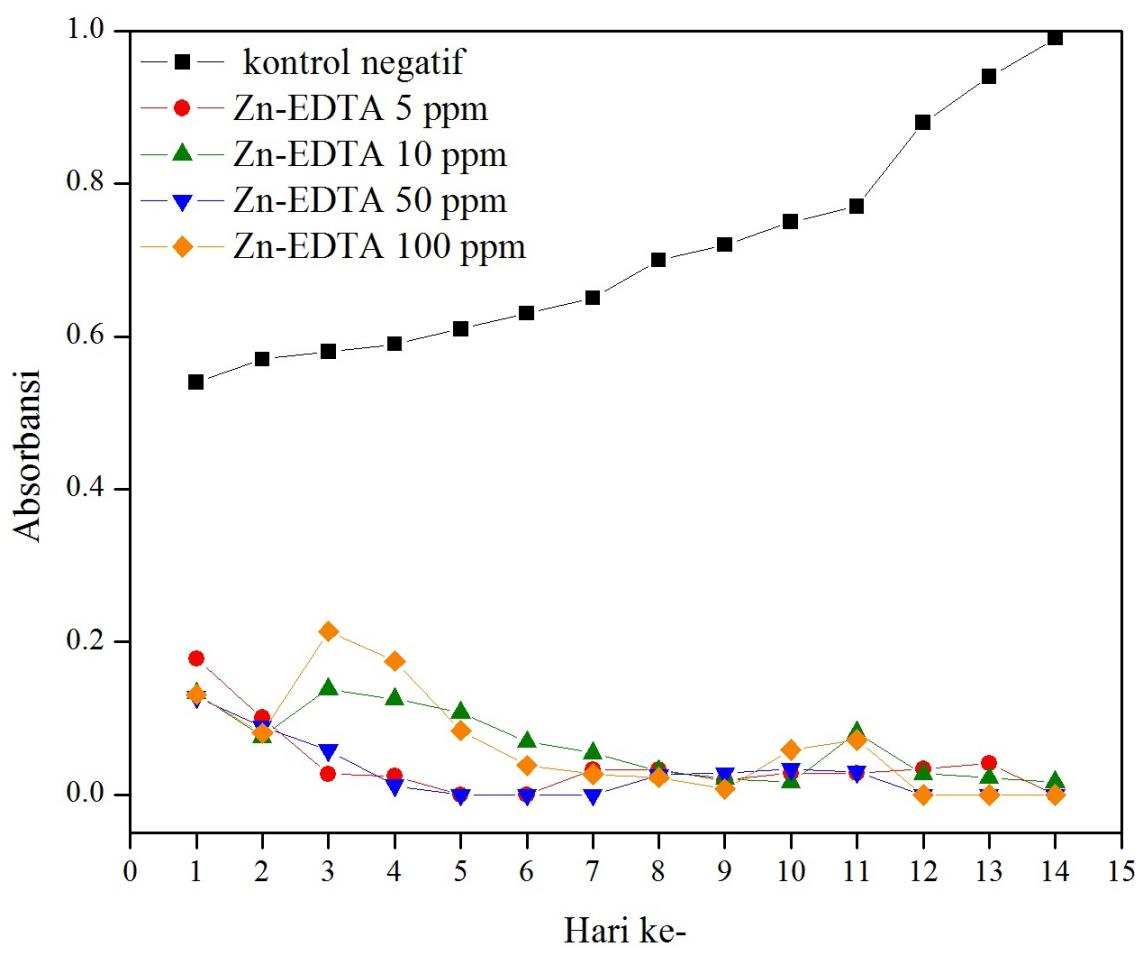

Gambar 3. Aktivitas penghambatan senyawa kompleks Zn(II)-EDTA pada pertumbuhan alga coklat 
Gambar 2 dan 3 menunjukkan bahwa ketika sampel cooling water tidak diberi perlakuan apapun, pertumbuhan alga hijau dan coklat semakin meningkat setiap harinya. Hal ini terlihat dari tingginya jumlah alga pada sampel yang dilambangkan dari nilai absorbansi perpendaran alga yang terukur dengan spektrofotometer UV-VIS. Ketika sampel cooling water yang mengandung alga diberi perlakuan dengan senyawa kompleks Zn(II)-EDTA, terlihat bahwa pertumbuhan alga dapat dihambat setiap harinya. Hal ini dibuktikan dengan rendahnya nilai absorbansi perpendaran alga yang terukur baik pada alga hijau ataupun coklat. Ketika sampel cooling water diberi senyawa kompleks Zn(II)EDTA jumlah alga pada sampel cooling water dapat ditekan hingga $97 \%$ untuk alga hijau dan 99\% untuk alga coklat jika dibandingkan dengan sampel tanpa perlakuan apapun. Hal ini membuktikan bahwa senyawa kompleks Zn(II)-EDTA sangat potensial menghambat pertumbuhan alga dalam sampel cooling water.
Pada penelitian ini, potensi penghambatan pertumbuhan alga yang dimiliki senyawa kompleks Zn(II)-EDTA dibandingkan dengan kontrol positif Seyton yang merupakan produk komersil penghambat pertumbuhan alga yang sering dipakai di berbagai industri. Hasil perbandingan kemampuan penghambatan alga senyawa kompleks Zn(II)-EDTA dan Seyton disajikan pada Gambar 4. Gambar 4 menunjukkan bahwa senyawa kompleks Zn(II)-EDTA memiliki kemampuan penghambatan yang lebih tinggi pada pertumbuhan alga dibandingkan kontrol positifnya yaitu Seyton. Senyawa kompleks Zn(II)-EDTA mampu menghambat pertumbuhan alga sebesar $98 \%$ untuk alga hijau dan $87 \%$ untuk alga coklat jika dibandingkan dengan sampel dengan perlakuan Seyton. Hasil ini membuktikan bahwa senyawa kompleks $\mathrm{Zn}(\mathrm{II})$-EDTA lebih berpotensi menghambat pertumbuhan alga dibandingkan senyawa komersiil yang sering dipakai industri selama ini.

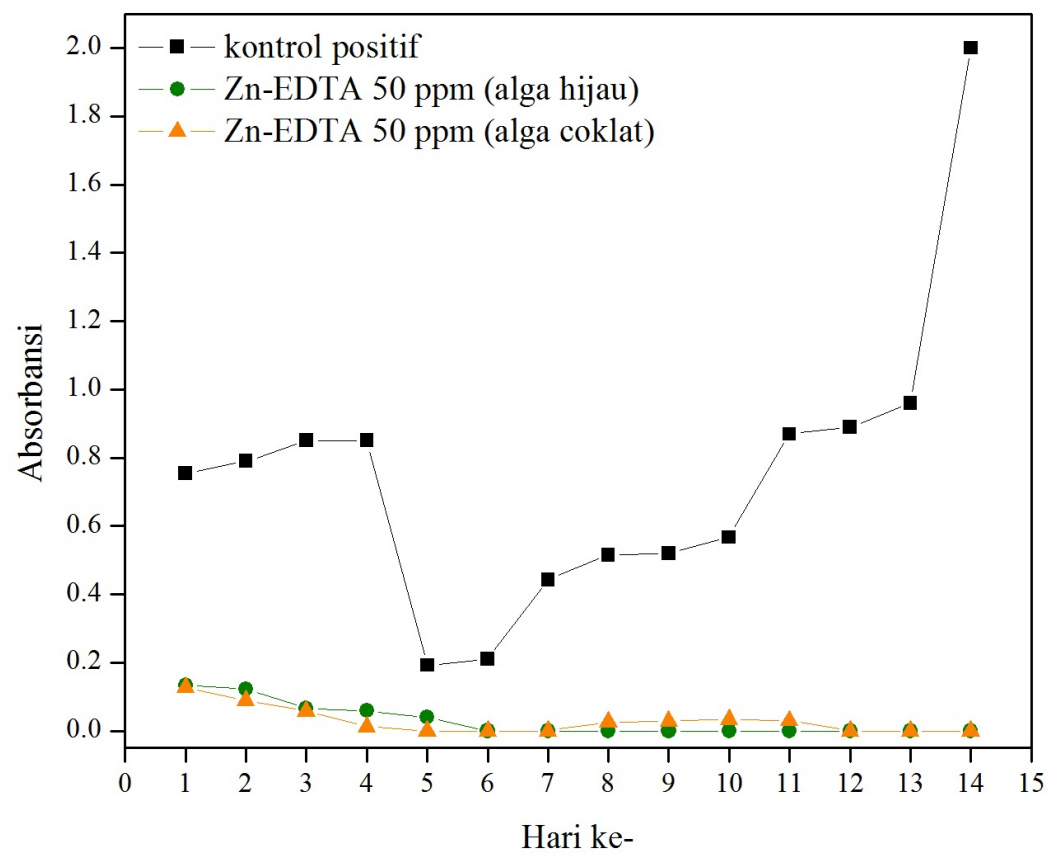

Gambar 4. Perbandingan uji aktivitas penghambatan pertumbuhan alga senyawa kompleks Zn-EDTA dengan kontrol positif Seyton. 
Uji aktivitas senyawa kompleks Zn(II)EDTA pada penghambatan pertumbuhan alga melalui analisis berat kering

Hasil uji aktivitas antialga senyawa kompleks Zn(II)-EDTA tehadap alga pada sampel cooling water disajikan pada Gambar 5. Berdasarkan Gambar 5, untuk sampel cooling water yang diberi pernambahan senyawa kompleks $\mathrm{Zn}$ (II)EDTA dapat dilihat bahwa pada hari pertama sampai hari kedua pertumbuhan alga mengalami peningkatan yang sedikit. Kemudian pada hari ketiga sampai hari ketujuh terjadi peningkatan pertumbuhan yang signifikan. Pada kondisi ini, alga mengalami pembelahan sel secara maksimal sehingga pertumbuhaannya cepat sekali. Sedangkan pada hari kedelapan sampai hari keempat belas pertumbuhan alga mulai mengalami penurunan secara pelan-pelan. Pada kondisi ini alga mulai mengalami penurunan pembelahan sel sampai pada akhirnya semua sel mati karena tidak dapat melakukan pembelahan sel lagi.
Untuk sampel yang diberi penambahan Seyton dan tanpa diberikan penambahan apa-apa grafik pertumbuhannya terus mengalami peningkatan jumlah sel. Artinya dengan sampel tanpa diberikan penambahan apa-apa maka alga akan mengalami pertumbuhan terus menerus tanpa dihambat pertumbuhannya. Sedangkan sampel yang diberikan senyawa Seyton juga mengalami pertumbuhan terus menerus meskipun sudah dihambat pertumbuhannya. Hal ini dikarenakan senyawa Seyton yang ditambahkan kemampuan untuk membunuh alga kurang maksimal dibandingkan dengan kemampuan alga tumbuh setiap harinya. Hasil uji aktivitas ini menyimpulkan bahwa senyawa kompleks Zn(II)-EDTA terbukti memiliki kemampuan penghambatan pertumbuhan alga yang lebih baik jika dibandingkan senyawa komersial Seyton yang biasa digunakan di industri untuk menghambat pertumbuhan alga.

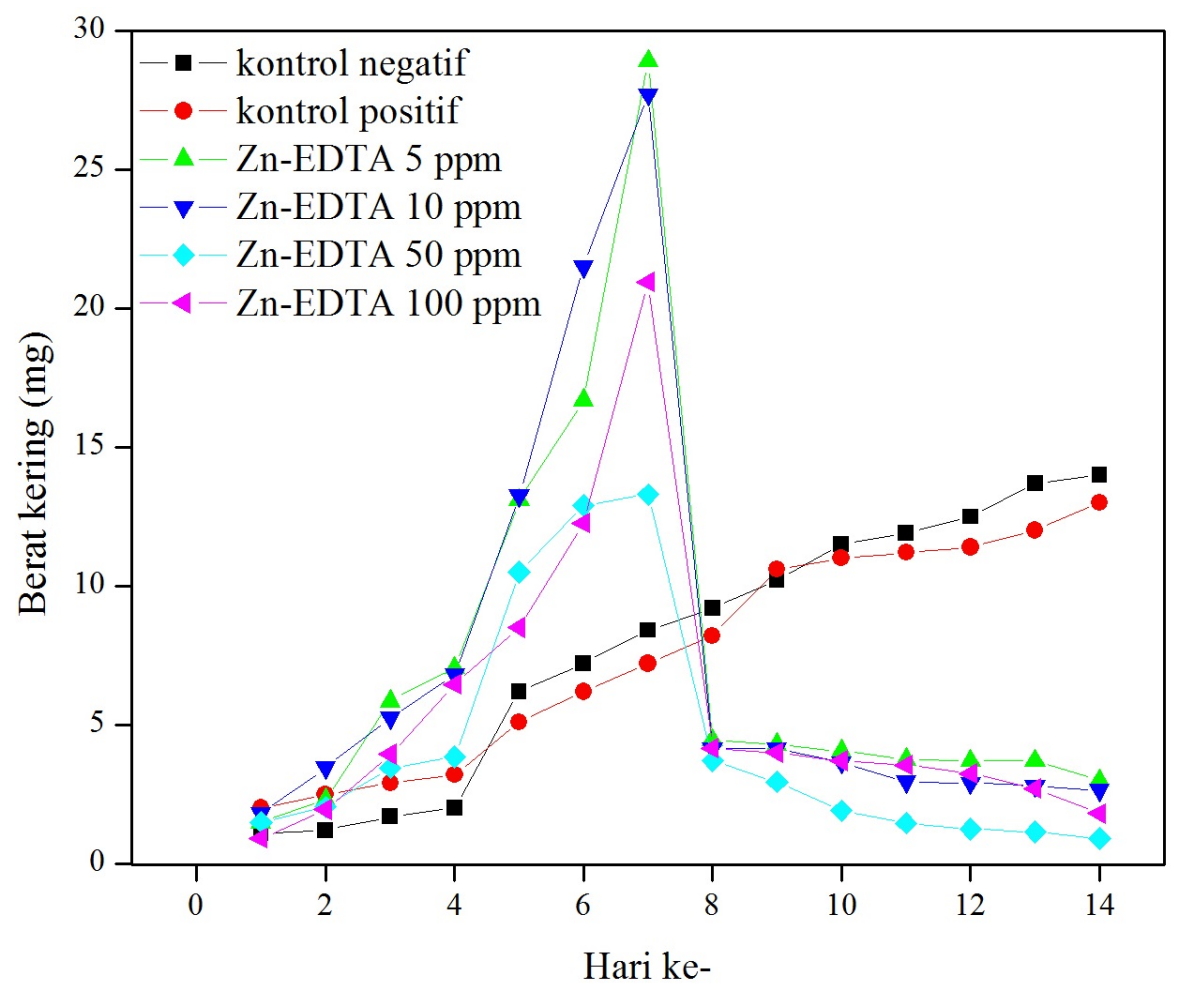

Gambar 5. Analisis Berat Kering Alga 


\section{Kesimpulan}

Senyawa kompleks Zn(II)-EDTA berhasil disintesis dari senyawa $\mathrm{ZnCl}_{2}$ anhidrat dan $\mathrm{Na}_{2}$ EDTA dengan perbandingan mol logam:ligan $=1: 1$. Senyawa kompleks Zn(II)-EDTA memiliki karakteristik panjang gelombang maksimal $752 \mathrm{~nm}$; ikatan Zn-O dari ligan EDTA muncul pada serapan 478,35

\section{Daftar Pustaka}

Hendayana, Sumar, dkk. 1994. Inorganic Chemistry. New Jersay: Prentice- Hall Inc.

Palomino, A.G. 2006. Room Temperature Sybthesis and Characterization of Highly Monodisperse Transition MetalDoped ZnO Nanocrystals. Physics. University of Puerto Rico.

Paten No. 2002098231 A1, Method and Apparatus for Preventing Bacteria and Algae Growth in Water

Setiyani, R. \& Kartika, M.D. 2015. Pemanfaatan Komposit Kitosan Zn-O$\mathrm{SiO}_{2}$ sebagai Agen Antibakteri Terhadap Bakteri Staphylococcus $\mathrm{cm}^{-1}$ dan ikatan $\mathrm{Zn}-\mathrm{N}$ dari ligan EDTA muncul pada serapan 516,92 $\mathrm{cm}^{-1}$. Senyawa kompleks Zn(II)-EDTA pada konsentrasi 50 ppm terbukti mampu menghambat pertumbuhan alga hijau hingga $98 \%$ dan alga coklat hingga 87\% jika dibandingkan dengan kontrol positif Seyton.

aureus Pada Kain Katun. Jurnal of Chemistry, Vol 4. No.2

Tarasov, Konstantin, Patricia B., Michel C., Eric M., Ynling L., 2011, Genesis of Supported Crabon-coated Co Nanoparticles with Controlled Magnetic Properties, Prepared by Decomposition of Chelate Complexes, JJ Nanopart Res., 13: 1873-1887.

Widiasa, N.I., dkk. 2005. Rekayasa Kontaktor Hollow Fiber Longitudinal sebagai Closed Recirulation Modular Cooling Water untuk Optimalisasi Penggunaan Air dan Energi di Industri Semarang: Fakultas Teknik Universitas Diponegoro. 